\title{
Content-Based Recreational Book Reading and Taiwanese Adolescents' Academic Achievement
}

\author{
Su-Yen Chen ${ }^{1}$, Hsing-Yu Chang ${ }^{1} \&$ Shih Ruey Yang $^{2}$ \\ ${ }^{1}$ Institute of Learning Sciences, National Tsing Hua University, Hsinchu, Taiwan \\ ${ }^{2}$ Taipei First Girls High School, Taipei City, Taiwan \\ Correspondence: Su-Yen Chen, Institutue of Learning Sciences, Faculty of Education, 101. Sec.2. Kuang Fu Rd., \\ Hsinchu, 30013, Taiwan. E-mail: suychen@mx.nthu.edu.tw
}

Received: August 18, 2016

doi:10.5539/jel.v6n1p207

\begin{abstract}
The linkage between reading for pleasure and language ability has been well established, but the relationship between content-based recreational reading and academic achievement in various subject areas has rarely been explored. To investigate whether reading literature, social studies, and science trade books for pleasure is related to students' growth in achievement for the subjects of Chinese, social studies, and science, respectively, this study used data from 4,730 students at a Taiwanese girls' high school. Based on students' high school entrance exam test scores in three subject areas as control variables, and their college entrance exam scores as the outcomes, the findings indicated that pleasure reading in a specific content area might lead to growth in achievement for that particular content area, and in some cases, reading in other content areas might help as well. A reading program that invites students to engage in self-sponsored reading can promote disciplinary literacy and academic achievement.
\end{abstract}

Keywords: recreational reading, content area literacies, academic achievement, high school students, social studies, science

\section{Introduction}

Reading for pleasure is a key learning experience, regardless of a person's age. However, a high-stakes testing educational system may lead to "teaching to the test" at the secondary school level, with the result that adolescents may suffer from spending most of their time on academic-related activities rather than on recreational reading, a far-reaching educational practice (Chen \& Lu, 2009; Merga, 2016). Past researchers have concurred that the amount of free reading done by primary school students has a significant impact on their level of reading performance (Anderson, Wilson, \& Fielding, 1988; Greaney, 1980; Guthrie \& Greaney, 1991; Taylor, Frye, \& Maruyama, 1990). For secondary school students, researchers have likewise indicated that literacy outcomes positively influence their academic performance (Marks, McMillan, \& Hillman, 2001). In a review study, Mole and Bus (2011) meta-analyzed 99 studies that investigated the association between print exposure and components of reading across preschoolers, students in grades 1-12, and college students, and confirmed that reading for pleasure is connected to language ability for all levels of students. Their main findings are consistent with a developmental model of reading comprehension and technical reading and spelling, in which print exposure is considered to play an important role in shaping literacy. The researchers also found moderate associations between print exposure and academic achievement for college students. But are content and subject areas important factors to consider when examining the linkages between reading amount and academic achievement? Can content-based recreational book reading help students' learning in the disciplines, especially for adolescents?

Although researchers have examined the broad connections between reading and academic achievement, the linkages between content-based pleasure reading and academic achievement for a content area have been left relatively unexplored. Hence, we conducted a study at a Taiwanese girls' high school to determine whether reading literature, social studies, and science trade books for pleasure is related to students' growth in achievement for the subjects of Chinese, social studies, and science. 


\section{Research on Adolescent Literacy}

According to the International Reading Association (IRA), which changed its name to the International Literacy Association (ILA) in 2015, adolescent literacy is attracting increasing attention from researchers and teachers alike, and a special focus has been on disciplinary literacy and access to authentic reading materials (International Reading Association, 2012). Lai, Wilson, McNaughton, and Hsiao (2014) have distinguished between generic literacy and content area literacy: the former refers to literacy that is applicable to all content areas, while the latter relates to the specialized features of texts in particular content areas, including knowledge about the organizational, lexical, and grammatical features of content-area texts. Fang and Coatoam (2013), in contrast, attempted to differentiate disciplinary literacy from content-area literacy. Content-area literacy focuses on developing students' ability to effectively use reading and writing as tools for learning from content-area texts, whereas disciplinary literacy aims at developing their ability to engage in social, semiotic, and cognitive practices consistent with those used by content experts. Moje (2008) suggested that secondary education should help students build an understanding of how knowledge is produced in the disciplines, rather than just construct knowledge in the disciplines. In other words, according to Moje, students need to learn how the disciplines are different from one another, how acts of inquiry produce knowledge, and how the differences in disciplines are socially constructed. Nevertheless, how can students learn discipline-specific language skills, literate practices, and habits of mind (Fang \& Coatoam, 2013; Fang \& Schleppegrell, 2010; Wilson, 2011)? Several researchers have made an effort to address this question.

First, Snow (2010) proposed that many high school students have difficulty converting their word-reading skills into comprehension when confronted with texts in science and the social sciences due to "academic language" that may disrupt their reading comprehension and block learning. Content experts usually use sophisticated words and complex grammatical constructions in order to be concise, precise, and authoritative. Snow pointed out that some students can acquire academic vocabulary on their own by reading widely, but at the same time, schools can provide high-interest material and implement effective instructional design to offer disciplinary literacy support for middle school students (Duhaylongsod, Snow, Selman, \& Nonovan, 2015).

Second, past research has indicated that compared to textbooks, informational trade books about the natural or social world provide qualitatively different opportunities for students to construct knowledge in at least two ways: trade books present rich language patterns that are contextualized in descriptions, and they offer an entryway into the wonders of science, history, or other content areas (Saul \& Dieckman, 2005). Trade books portray science, for example, as it is practiced in the real world; they offer more focused, in-depth, and up-to-date coverage of content; and they are better able to accommodate the needs of different students than can textbooks (Fang, 2013). Reeves (2004) also proposed that, if teachers assign informational readings that are interesting as recreational reading materials, students' reading interest and ownership might enhance their academic achievement, a claim echoed by many secondary content-area preservice teachers who regard the offering of a variety of reading material to their future students as having a significant impact on their learning (Daisey, 2010).

Furthermore, scholars who study literacy through a sociocultural lens consider out-of-school literacy to be both a bridge and a resource for helping students develop content-area and disciplinary literacy (Fang, 2012). In a study that explored the complex world of adolescent literacy, Moje, Overby, Tysvaer, and Morris (2008) found that reading for pleasure was positively related to students' grades in English and science as well as their cumulative Grade Point Average (GPA), but that the frequency of novel reading was related only to students' English grade and GPA. They proposed that genre, content, and subject area are important factors to consider when examining the linkage between time spent reading and academic achievement. For example, science achievement is more likely to be bolstered by reading science texts and history achievement by reading history. Unfortunately, almost no study has addressed the association between content-based pleasure reading and growth in achievement for the content area.

\section{The Taiwan Context}

In Taiwan, most teenagers spend a lot of time on academic-related activities. In one study that used a nationally representative sample with data from 10,347 Taiwanese $11^{\text {th }}$ graders, for example, Chen and Lu (2009) found that, on average, students spent about the same number of hours each day on homework and on watching television or videos, both for $1.92 \mathrm{~h}$. They also spent time each week on other after-school activities, including academic enrichment programs $(4.35 \mathrm{~h})$, Internet games $(4.0 \mathrm{~h})$, private cram (intensive learning) schools $(2.85$ h), school-based extracurricular activities $(1.76 \mathrm{~h})$, part-time employment $(1.73 \mathrm{~h})$, and extracurricular reading $(0.97 \mathrm{~h})$. They engaged in sports three times per week, on average. A hierarchical regression analysis found that, in addition to the student's educational achievement in the previous year and the father's educational level and 
family income, time spent on six out of nine after-school activities during the $11^{\text {th }}$ grade also helped predict educational achievement in the $12^{\text {th }}$ grade: homework, after-school academic-enrichment programs, private cram schools, extracurricular reading, watching television or videos, and part-time employment. While high school students increased their academic achievement by spending time on homework, after-school academic-enrichment programs, private cram schools, and extracurricular reading, time spent watching television or videos and on part-time employment yielded a negative effect.

In another effort to understand Taiwan students' reading and literacy, Chen and Fang (2016) developed a title recognition test and an author recognition test as measures of objective print exposure for Taiwanese fifth graders. They found that print exposure had substantial prediction power for their vocabulary size and also for their reading comprehension beyond vocabulary size. For older students, Chen and Fang (2015) used an author recognition test score as the indicator for print exposure and found that primary print knowledge scores have prediction power for both the General Scholastic Ability Test (GSAT)-Chinese and the Department Required Test (DRT)-Chinese beyond the joint contributions of vocabulary size and reading comprehension. In other words, these studies established relationships between print exposure and vocabulary size as well as reading comprehension for primary-school students, and between print exposure and scores on two general reading achievement tests for college students.

The current study goes beyond the previous research to examine whether reading literature, social studies, and science trade books for pleasure is related to growth in achievement for the subjects of Chinese, social studies, and science for students at a Taiwanese girls' high school.

\section{4. "Reading for Pleasure" at Zhong Shan Girls' High School}

Taipei Municipal Zhong Shan Girls' High School (hereafter Zhong Shan) was founded in 1897 as the pioneer girls' high school in Taiwan. As a prestigious three-year senior-high school, there are currently 73 classes with up to 3,000 students. Like other high schools in Taiwan, students can choose between two broad categories of programs that relate to their future major of study that they will select on entering the tenth grade, namely, the Humanities \& Social Sciences class and the Math \& Science class. Both classes are required to study Chinese, English, and math. In addition, students in the Humanities \& Social Sciences class must take extra humanities and social science courses, such as history, geography, politics, economics, and philosophy, while those in the Math \& Science class have to take extra math and science courses, including biology, physics, and chemistry.

In line with Zhong Shan's positive school spirit, it promotes the school-wide "Reading for Pleasure" program, which is focused on encouraging students to engage in self-sponsored reading. Since 2003, this program has been supported by an online reading certification system designed by Zhong Shan. On the platform website, students can find a reading list of books recommended by teachers from various disciplines. Although most titles can be classified into different disciplines, for the purpose of the present study, the titles on the list are sorted by genres around three broad content areas: literature, social studies, and science. Sometimes new book titles are added and occasionally a few are removed from the list, but overall, the number of titles has remained relatively stable. All books are written in Chinese, although some are translated from other languages.

For each title, an introduction as well as book reviews and peer reviews are provided for the students' information. Students can take a certification test once they have finished reading a book, and the test results are recorded on the platform. The platform also makes it possible to calculate several key pieces of information for each month: the number of books read by each student, by each class as a unit, and by month as a unit as well as popularity rankings among books. For each semester, the top-three avid readers are awarded an honorary certificate, and students are also rewarded according to their total reading amount over the three-year period of their enrollment. Moreover, students' reading engagement on the "Reading for Pleasure" platform can be used as a portfolio for demonstrating their enthusiasm for reading when they submit their college applications.

\section{Data Collection and Analysis}

We collected data from five cohorts of students, those who enrolled at Zhong Shan as 10th graders between academic years between 2004 and 2008 and graduated between 2007 and 2011, with a total number of 4,730. Among these students, 2,563 were enrolled in the Humanities \& Social Sciences classes and 2,167 belonged to the Math \& Science classes. Graduates from recent years were not included because the entrance exam for high school was revised in 2009.

The data that we utilized consisted of students' amounts of reading in the three content areas (literature, social studies, and science) over the three-year period and six test scores. The three reading amounts were recorded from the "Reading for Pleasure" platform. It is important to note that we used the amount of book reading as an 
indicator for individual students' general reading engagement in three content areas outside of the classroom, rather than the exact number of books that students read for pleasure. We believe that students read beyond the list and engaged in much more self-sponsored reading than indicated by the recorded number.

The complete titles that appeared on the "Reading for Pleasure" list during the five academic years from 2007 to 2011 are shown in Table 1 as well as the occurrence rates of the books on the list and the number of students who finished reading them. In each content area, the number of book titles was quite stable over the five years, with the titles ranging from 21 to 23 in the literature category, 15 to 17 in social studies, and 11 to 18 in science. The overall totals ranged from 47 to 56 , and there were 58 book titles in total for the five-year period. To be specific, among the five-year total titles, around $40 \%$ are literature and $60 \%$ are informational books, or nonfiction. The recreational reading profiles of Taiwanese college students indicated that they read $60 \%$ literature, or fiction, and $40 \%$ informational books, or nonfiction, in their leisure time.

Table 1. Selected book titles and their broad content areas, specific disciplines, occurrence rates, and reading rates

\begin{tabular}{|c|c|c|c|c|}
\hline Content Area & Discipline & Book Title & $\begin{array}{c}\text { Occurren } \\
\text { ce }\end{array}$ & $\begin{array}{c}\text { Reading } \\
\text { Rates }\end{array}$ \\
\hline \multirow[t]{23}{*}{ Literature } & Chinese Literature & A Thousand Moons on a Thousand Rivers & 5 & 2647 \\
\hline & Chinese Literature & The Border Town & 5 & 2515 \\
\hline & Chinese Literature & Taipei People & 5 & 2420 \\
\hline & Chinese Literature & The Story of the Stone & 5 & 2361 \\
\hline & Foreign Literature & Tuesdays with Morrie* & 5 & 2069 \\
\hline & Chinese Literature & Dream Shadows & 5 & 1362 \\
\hline & Chinese Literature & Love in a Fallen City & 5 & 1290 \\
\hline & Foreign Literature & Stray Birds* & 5 & 889 \\
\hline & Chinese Literature & Romance of the Three Kingdoms & 5 & 529 \\
\hline & Chinese Literature & $\begin{array}{l}\text { san wen du ben tai wan xian dai wen xue jiao cheng (in } \\
\text { Chinese) }\end{array}$ & 5 & 289 \\
\hline & Chinese Literature & Best Stories of Lu Xun & 5 & 259 \\
\hline & Chinese Literature & Cultural Odyssey & 3 & 191 \\
\hline & Biography & The Gay Genius: The Life and Times of Su Tungpo & 5 & 188 \\
\hline & Chinese Literature & shan ju bi ji (in Chinese) & 5 & 143 \\
\hline & Chinese Literature & The Human Child and Legend Stories & 5 & 123 \\
\hline & Chinese Literature & xiao shi xuan du (in Chinese) & 5 & 114 \\
\hline & Biography & Lust for Life: Vincent Willem van Gogh* & 5 & 100 \\
\hline & Chinese Literature & Collection of $\mathrm{Ci}$ and $\mathrm{Qu}$ & 5 & 73 \\
\hline & Foreign Literature & World Literature Classic & 5 & 67 \\
\hline & Chinese Literature & tian xia san wen xuan (in Chinese) & 5 & 33 \\
\hline & Chinese Literature & bai nian si suo (in Chinese) & 5 & 33 \\
\hline & Chinese Literature & kua shi ji feng hua dang dai xiao shuo er shi jia (in Chinese) & 5 & 13 \\
\hline & Foreign Literature & A Thousand Splendid Suns* & 1 & 1 \\
\hline Social & Sociology/Civic Education & Thinking Sociologically* & 4 & 869 \\
\hline \multirow[t]{3}{*}{ Sciences } & Psychology/Civic Education & Self-clarification: From the Psychological View & 5 & 863 \\
\hline & Social Science & lian ren fa ting (in Chinese) & 5 & 510 \\
\hline & Political Science & zheng zhi sha wan yi (in Chinese) & 2 & 308 \\
\hline
\end{tabular}




\begin{tabular}{|c|c|c|c|c|}
\hline & History/Geography & kui kan ou zhou (in Chinese) & 5 & 174 \\
\hline & History/Geography & fa xian tai wan (in Chinese) & 5 & 168 \\
\hline & History/Geography & $\begin{array}{l}\text { xiao fan shu bian da du po ni cong mei xiang guo de tai } \\
\text { wan di li qu shi (in Chinese) }\end{array}$ & 5 & 152 \\
\hline & History/Geography & kui kan yin du (in Chinese) & 5 & 144 \\
\hline & History/Geography & Looking at Taiwan & 5 & 86 \\
\hline & History/Geography & The Wonders of the World* & 5 & 76 \\
\hline & History/Geography & shang tian xia di kan jia yuan (in Chinese) & 5 & 64 \\
\hline & History/Geography & he xun he pan tan zhong guo li shi (in Chinese) & 5 & 43 \\
\hline & History/Geography & $\begin{array}{l}\text { nan fang yi nan sha zhong zhi sha nan ji bei fei yin xiang } \\
\text { (in Chinese) }\end{array}$ & 5 & 38 \\
\hline & History/Geography & 100 Interesting Ways to See the World Map* & 5 & 35 \\
\hline & History & cong li shi kan ling dao (in Chinese) & 5 & 19 \\
\hline & History/Geography & Where Khan's Falcon Flies* & 5 & 18 \\
\hline & History/Geography & An Area of Darkness* & 4 & 12 \\
\hline Sciences & Physics & fa la di de gu shi (in Chinese) & 5 & 2455 \\
\hline & Earth Science & Earth in the Balance : Ecology And Human Spirit* & 5 & 1100 \\
\hline & Physics & $\begin{array}{l}\text { Perfectly Reasonable Deviations from the Beaten Track } \\
\text { The Letters Of Richard P. Feynman* }\end{array}$ & 5 & 763 \\
\hline & Nutritional Sciences & Diet For A New America* & 5 & 723 \\
\hline & Nutritional Sciences & $\begin{array}{l}\text { Fast Food Nation: The Dark Side of the All-American } \\
\text { Meal* }\end{array}$ & 4 & 657 \\
\hline & Biology & The Enzyme Factor* & 4 & 652 \\
\hline & Biology & Reclaiming Our Health* & 4 & 647 \\
\hline & Chemistry & zhi ming de he cheng xi ji (in Chinese) & 4 & 631 \\
\hline & Environmental Sciences & Stuff: The Secret Live of Everyday Thing* & 4 & 626 \\
\hline & Biology & King Solomon's Ring* & 5 & 431 \\
\hline & Natural Sciences & Weighing the Soul: The Evolution of Scientific Beliefs* & 3 & 291 \\
\hline & Physics & How to Dunk a Doughnut : The Science of Everyday Life* & 5 & 172 \\
\hline & Chemistry & The Genie in the Bottle* & 5 & 162 \\
\hline & Physics & The Cartoon Guide to Physics* & 5 & 114 \\
\hline & Earth Science & How to Build a Habitable Planet* & 5 & 111 \\
\hline & Biology & Why We Hurt : The Natural History of Pain* & 5 & 111 \\
\hline & Physics & Alice in Quantumland* & 5 & 63 \\
\hline & Physics & Physics Over Easy* & 1 & 3 \\
\hline
\end{tabular}

Occurrence: Number of years on the list.

Reading Rates: Number of students finished reading.

*Translated books.

In addition, among these complete titles, $57 \%$ are written by Chinese authors and $43 \%$ are translated works. Taiwanese college students' self-sponsored book reading profiles suggested that they read $60 \%$ translated works (Chen \& Fang, 2015). In other words, the "Reading for Pleasure" list consists of proportionally more informational titles, or nonfiction, than the average number that students read in their spare time. Regarding the 
distribution of disciplines or genres within each content area, among the 23 titles in the content area of literature, $70 \%$ are Chinese literature, $20 \%$ are foreign literature, and 10\% are biography. Among the 17 titles in the content area of social studies, $80 \%$ are related to history/geography, and only $20 \%$ are related to civic education/psychology/sociology/political science. Finally, among the 18 titles in the content area of science, $30 \%$ are related to physics, $30 \%$ are related to biology, and $40 \%$ are related to chemistry/earth sciences/nutritional sciences/environmental sciences.

For the test scores, we used students' high school entrance exam test scores in the three subject areas as control variables and their college entrance exam test scores as the academic outcome. To be specific, the Basic Competence Test (BCT) for Junior High School Students is a standardized exam for junior high school students in Taiwan. Students are required to take the BCT to apply for admission to senior high school. The BCT includes five subjects: Chinese, English, mathematics, social studies, and science. For each subject area, the scaled score ranges from 0 to 60 , with a total maximum score of 300. In January of each year, senior high school students take the GSAT as a standard means of entry into Taiwanese universities and colleges that assesses their basic competence in Chinese, English, mathematics, social studies, and science. For each subject area, the scaled score ranges from 0 to 15 , with a total maximum score of 75 . Students then seek recommendations from their school or make their own application to institutions of their choice. For the purpose of the present study, only Chinese, social studies, and science test scores from the BCT and the GSAT were selected for analysis.

We conducted the data analysis using Pearson moments correlation and hierarchical regression analysis. To explore whether students' academic aptitude plays any role in the relationship between content-based pleasure reading and academic achievement, we divided our participants into two groups: the Humanities \& Social Sciences majors-to-be and the Math \& Science majors-to-be. Then, in the regression models, the GSAT Chinese score, the GSAT Social Studies score, and the GSAT Science score were three dependent variables. For the regression model on the GSAT Chinese score, the BCT Chinese score was entered first as the control variable, and then the reading amounts in literature, in social studies, and in science were entered separately to investigate the relative extent to which they predicted growth in Chinese achievement. Similarly, for the regression model on the GSAT Social Studies score, the BCT Social Studies score was entered first as the control variable, and then the reading amounts in literature, in social studies, and in science were entered separately to investigate the relative extent to which they predicted growth in social studies achievement. And finally, for the regression model on the GSAT Science score, the BCT Science score was entered first as the control variable, and then the reading amounts in literature, in social studies, and in science were entered separately to investigate the relative extent to which they predicted growth in science achievement.

\section{Positive Effects of Content-Based Recreational Reading}

Our study resulted in several findings that help us better understand the role of pleasure reading and how it relates to academic achievement. The female high school who were the subjects of our study read an average of 3.75 titles in literature, 0.76 titles in social studies, and 2.05 titles in science trade books, and an average of 6.56 titles across genres over the three-year period (see Table 2 for the statistical details). The results were not quite consistent with the common impression that reading choices are usually skewed toward fiction. When we examined the students' reading preferences more closely, we found only 5 books that were read by $50 \%$ of the students, with 4 on Chinese literature and 1 nonfiction book about Michael Faraday, while 21 books were read by $10 \%$ of the students, with 9 from the content area of literature, 3 from social studies, and 9 from science, as shown in Table 1. Among these popular titles, 7 out of 9 are Chinese literature in the content area of literature; all 3 books in the content area of social science are related to that field in a broader sense rather than to history/geography specifically; and the 9 titles in the content area of sciences cover a wide range of disciplines, from physics, biology, and nutritional sciences to earth sciences, environmental sciences, and chemistry.

Table 2. Mean reading amounts (with SDs) of literature, social studies, and science trade books

\begin{tabular}{lcccccc}
\hline Book Genre & $\mathrm{N}$ & Obtained Range & Min & Max & Mean & SD \\
\hline Literature books & 4730 & $0-23$ & 0 & 23 & 3.75 & 2.32 \\
Social Studies books & 4730 & $0-17$ & 0 & 15 & 0.76 & 1.39 \\
Science books & 4730 & $0-18$ & 0 & 16 & 2.05 & 2.39 \\
Total & 4730 & $0-56$ & 1 & 49 & 6.56 & 4.61 \\
\hline
\end{tabular}


When looking at the data with respect to the two student groups, we found that Humanities \& Social Sciences majors-to-be read significantly more social studies and science trade books than did the Math \& Science majors-to-be, while there was no significant difference between the two groups in the amount of literature read, as shown in Table 3 .

Table 3. Difference between literature, social studies, and science reading amounts by academic groups

\begin{tabular}{|c|c|c|c|c|c|}
\hline Book Genre & Academic groups & $\mathrm{N}$ & Mean & $\mathrm{SD}$ & $\mathrm{t}$ \\
\hline \multirow[t]{2}{*}{ Literature books } & $\begin{array}{l}\text { Students in Humanities \& Social } \\
\text { Sciences classes }\end{array}$ & 2563 & 3.81 & 2.41 & \multirow[t]{2}{*}{1.917} \\
\hline & Students in Math \& Science classes & 2167 & 3.68 & 2.21 & \\
\hline \multirow[t]{2}{*}{ Social Studies books } & $\begin{array}{l}\text { Students in Humanities \& Social } \\
\text { Sciences classes }\end{array}$ & 2563 & 0.83 & 1.59 & \multirow[t]{2}{*}{$3.996 * * *$} \\
\hline & Students in Math \& Science classes & 2167 & 0.67 & 1.10 & \\
\hline \multirow[t]{2}{*}{ Science books } & $\begin{array}{l}\text { Students in Humanities \& Social } \\
\text { Sciences classes }\end{array}$ & 2563 & 2.35 & 2.68 & \multirow[t]{2}{*}{$9.662 * * *$} \\
\hline & Students in Math \& Science classes & 2167 & 1.70 & 1.93 & \\
\hline
\end{tabular}

For the Humanities \& Social Sciences majors-to-be, we found that (a) reading literature and social studies trade books significantly predicted growth in Chinese achievement, (b) reading social studies and science trade books was a significant predictor for growth in social studies achievement, and (c) reading literature, social studies, and science trade books was a significant predictor for growth in science achievement (see Table 4). We can make several interesting observations from these findings. First, overall, students benefit from reading various kinds of books. Second, to be specific, reading literature, in addition to social studies trade books, benefits students' Chinese achievement; reading social studies and science trade books benefits their social science achievement; and reading science trade books as well as literature and social science trade books benefits their science achievement. These results seem to support that reading trade books in certain content areas enhances academic achievement corresponding to the same content area. Moreover, in addition, and most interestingly, our results indicate that reading social studies trade books enhanced achievement growth across all three content areas for the Humanities \& Social Sciences majors-to-be.

Table 4. Hierarchical regressions of BCT scores, literature, social studies, and science reading amounts on GSAT scores for students in humanities \& social sciences classes

\begin{tabular}{|c|c|c|c|c|c|c|c|c|c|c|c|c|c|c|}
\hline \multicolumn{5}{|c|}{ GSAT Chinese scores } & \multicolumn{5}{|c|}{ GSAT Social Studies scores } & \multicolumn{5}{|c|}{ GSAT Science scores } \\
\hline & $\begin{array}{c}\text { Mod } \\
\text { el } 1\end{array}$ & $\begin{array}{c}\text { Mod } \\
\text { el } 2\end{array}$ & $\begin{array}{c}\text { Mod } \\
\text { el } 3\end{array}$ & $\begin{array}{c}\text { Mod } \\
\text { el } 4\end{array}$ & & $\begin{array}{l}\text { Mod } \\
\text { el } 1\end{array}$ & $\begin{array}{l}\text { Mod } \\
\text { el } 2\end{array}$ & $\begin{array}{c}\text { Mod } \\
\text { el } 3\end{array}$ & $\begin{array}{c}\text { Mod } \\
\text { el } 4\end{array}$ & & $\begin{array}{c}\text { Model } \\
1\end{array}$ & $\begin{array}{c}\text { Mod } \\
\text { el } 2\end{array}$ & $\begin{array}{c}\text { Mod } \\
\text { el } 3\end{array}$ & $\begin{array}{c}\text { Mod } \\
\text { el } 4\end{array}$ \\
\hline $\begin{array}{l}\text { BCT } \\
\text { Chinese } \\
\text { scores }\end{array}$ & $\begin{array}{l}.148 \\
* * *\end{array}$ & $\begin{array}{l}.150 \\
* * *\end{array}$ & $\begin{array}{l}.147 \\
* * *\end{array}$ & $\begin{array}{c}.148^{*} \\
* *\end{array}$ & $\begin{array}{l}\text { BCT } \\
\text { Social } \\
\text { Studies } \\
\text { scores }\end{array}$ & $\begin{array}{l}.181 \\
* * *\end{array}$ & $\begin{array}{l}.181 \\
* * *\end{array}$ & $\begin{array}{l}.189 \\
* * *\end{array}$ & $\begin{array}{l}.204 \\
* * *\end{array}$ & $\begin{array}{l}\text { BCT } \\
\text { Science } \\
\text { scores }\end{array}$ & $\begin{array}{c}.254^{*} \\
* *\end{array}$ & $\begin{array}{c}.263^{*} \\
* *\end{array}$ & $\begin{array}{c}.256^{*} \\
* *\end{array}$ & $\begin{array}{c}.259^{*} \\
* *\end{array}$ \\
\hline $\begin{array}{l}\text { Literatur } \\
\text { e books }\end{array}$ & & $\begin{array}{l}.082 \\
* * *\end{array}$ & & & $\begin{array}{l}\text { Literatur } \\
\text { e books }\end{array}$ & & -.006 & & & $\begin{array}{l}\text { Literatu } \\
\text { re } \\
\text { books }\end{array}$ & & $\begin{array}{c}.066^{*} \\
* *\end{array}$ & & \\
\hline $\begin{array}{l}\text { Social } \\
\text { Studies } \\
\text { books }\end{array}$ & & & $\begin{array}{c}.039 \\
*\end{array}$ & & $\begin{array}{l}\text { Social } \\
\text { Studies } \\
\text { books }\end{array}$ & & & $\begin{array}{l}.125 \\
* * *\end{array}$ & & $\begin{array}{l}\text { Social } \\
\text { Studies } \\
\text { books }\end{array}$ & & & $.040^{*}$ & \\
\hline $\begin{array}{l}\text { Science } \\
\text { books }\end{array}$ & & & & .008 & $\begin{array}{l}\text { Science } \\
\text { books }\end{array}$ & & & & $\begin{array}{l}.183 \\
* * *\end{array}$ & $\begin{array}{l}\text { Science } \\
\text { books }\end{array}$ & & & & $\begin{array}{c}.079 * \\
* *\end{array}$ \\
\hline
\end{tabular}




\begin{tabular}{|c|c|c|c|c|c|c|c|c|c|c|c|c|c|c|}
\hline $\mathrm{R}^{2}$ & .022 & .029 & .023 & .022 & $\mathrm{R}^{2}$ & .033 & .033 & .048 & .066 & $\mathrm{R}^{2}$ & .065 & .069 & .066 & .071 \\
\hline $\begin{array}{l}\mathrm{R}^{2} \\
\text { change }\end{array}$ & & $\begin{array}{l}.007 \\
* * *\end{array}$ & $\begin{array}{c}.002 \\
*\end{array}$ & .000 & $\begin{array}{l}\mathrm{R}^{2} \\
\text { change }\end{array}$ & & .000 & $\begin{array}{l}.016 \\
* * *\end{array}$ & $\begin{array}{l}.033 \\
* * *\end{array}$ & $\begin{array}{l}\mathrm{R}^{2} \\
\text { change }\end{array}$ & & $\begin{array}{c}.004 * \\
* *\end{array}$ & $.002 *$ & $\begin{array}{c}.006^{*} \\
* *\end{array}$ \\
\hline F & $\begin{array}{l}57.3 \\
4 * * *\end{array}$ & $\begin{array}{l}37.7 \\
0^{* * *}\end{array}$ & $\begin{array}{c}30.7 \\
3 * * *\end{array}$ & $\begin{array}{c}28.75 \\
* * *\end{array}$ & $\mathrm{~F}$ & $\begin{array}{l}86.3 \\
3 * * *\end{array}$ & $\begin{array}{l}43.2 \\
0 * * *\end{array}$ & $\begin{array}{l}64.8 \\
1 * * *\end{array}$ & $\begin{array}{l}89.8 \\
6^{* * *}\end{array}$ & $\mathrm{~F}$ & $\begin{array}{l}176.3 \\
3^{* * *}\end{array}$ & $\begin{array}{c}94.33 \\
* * *\end{array}$ & $\begin{array}{c}90.45 \\
* * *\end{array}$ & $\begin{array}{c}97.20 \\
* * *\end{array}$ \\
\hline
\end{tabular}

$* \mathrm{p}<.05 ; * * \mathrm{p}<.01 ; * * * \mathrm{p}<.001$.

For the second group, Math \& Science, (a) reading social studies trade books was a significant predictor for growth in Chinese achievement, (b) reading social studies and science trade books was a significant predictor for growth in social studies achievement, and (c) reading science trade books was a significant predictor for growth in science achievement (see Table 5). However, to be specific, first, unlike their counterparts, reading literature appeared to have no impact on Chinese achievement, even though these students read about the same amount of literature as the other group. However, reading social studies and science trade books did help them. Second, reading social studies trade books can help improve achievement in social studies and Chinese, and reading science trade books can help improve achievement in science and social studies. Again, these results seemed to support the theory that reading trade books in certain content areas enhances academic achievement corresponding to the same content area, with the exception of reading literature and Chinese achievement for these non-humanities-majors-to-be.

Table 5. Hierarchical regressions of BCT scores, literature, social studies, and science reading amounts on GSAT scores for students in math \& science classes

\begin{tabular}{|c|c|c|c|c|c|c|c|c|c|c|c|c|c|c|}
\hline \multicolumn{5}{|c|}{ GSAT Chinese scores } & \multicolumn{5}{|c|}{ GSAT Social Studies scores } & \multicolumn{5}{|c|}{ GSAT Science scores } \\
\hline & $\begin{array}{c}\text { Mod } \\
\text { el } 1\end{array}$ & $\begin{array}{c}\text { Mod } \\
\text { el } 2\end{array}$ & $\begin{array}{l}\text { Mod } \\
\text { el } 3\end{array}$ & $\begin{array}{c}\text { Mod } \\
\text { el } 4\end{array}$ & & $\begin{array}{l}\text { Mod } \\
\text { el } 1\end{array}$ & $\begin{array}{c}\text { Mod } \\
\text { el } 2\end{array}$ & $\begin{array}{c}\text { Mod } \\
\text { el } 3\end{array}$ & $\begin{array}{l}\text { Mod } \\
\text { el } 4\end{array}$ & & $\begin{array}{c}\text { Model } \\
1\end{array}$ & $\begin{array}{c}\text { Mod } \\
\text { el } 2\end{array}$ & $\begin{array}{c}\text { Mod } \\
\text { el } 3\end{array}$ & $\begin{array}{c}\text { Mod } \\
\text { el } 4\end{array}$ \\
\hline $\begin{array}{l}\text { BCT } \\
\text { Chinese } \\
\text { scores }\end{array}$ & $\begin{array}{l}.151 \\
* * *\end{array}$ & $\begin{array}{l}.151 \\
* * *\end{array}$ & $\begin{array}{l}.150 \\
* * *\end{array}$ & $\begin{array}{l}.151^{*} \\
* *\end{array}$ & $\begin{array}{l}\text { BCT } \\
\text { Social } \\
\text { Science } \\
\text { scores }\end{array}$ & $\begin{array}{l}.106 \\
* * *\end{array}$ & $\begin{array}{l}.109 \\
* * *\end{array}$ & $\begin{array}{l}.133 \\
* * *\end{array}$ & $\begin{array}{l}.115 \\
* * *\end{array}$ & $\begin{array}{l}\text { BCT } \\
\text { Science } \\
\text { scores }\end{array}$ & $\begin{array}{c}.247 * * \\
*\end{array}$ & $\begin{array}{c}.249^{*} \\
* *\end{array}$ & $\begin{array}{c}.246^{*} \\
* *\end{array}$ & $\begin{array}{l}.250 \\
* * *\end{array}$ \\
\hline $\begin{array}{l}\text { Literatur } \\
\text { e books }\end{array}$ & & -.001 & & & $\begin{array}{l}\text { Literatur } \\
\text { e books }\end{array}$ & & .029 & & & $\begin{array}{l}\text { Literat } \\
\text { ure } \\
\text { books }\end{array}$ & & .011 & & \\
\hline $\begin{array}{l}\text { Social } \\
\text { Studies } \\
\text { books }\end{array}$ & & & $\begin{array}{c}.062 \\
* *\end{array}$ & & $\begin{array}{l}\text { Social } \\
\text { Studies } \\
\text { books }\end{array}$ & & & $\begin{array}{l}.227 \\
* * *\end{array}$ & & $\begin{array}{l}\text { Social } \\
\text { Studies } \\
\text { books }\end{array}$ & & & -.012 & \\
\hline $\begin{array}{l}\text { Science } \\
\text { books }\end{array}$ & & & & .012 & $\begin{array}{l}\text { Science } \\
\text { books }\end{array}$ & & & & $\begin{array}{l}.120 \\
* * *\end{array}$ & $\begin{array}{l}\text { Science } \\
\text { books }\end{array}$ & & & & $\begin{array}{c}.044 \\
*\end{array}$ \\
\hline $\mathrm{R}^{2}$ & .023 & .023 & .027 & .023 & $\mathrm{R}^{2}$ & .011 & .012 & .062 & .026 & $\mathrm{R}^{2}$ & .061 & .061 & .061 & .063 \\
\hline $\begin{array}{l}\mathrm{R}^{2} \\
\text { change }\end{array}$ & & .000 & $\begin{array}{c}.004 \\
* *\end{array}$ & .000 & $\begin{array}{l}\mathrm{R}^{2} \\
\text { change }\end{array}$ & & .001 & $\begin{array}{l}.051 \\
* * *\end{array}$ & $\begin{array}{l}.014 \\
* * *\end{array}$ & $\begin{array}{l}\mathrm{R}^{2} \\
\text { change }\end{array}$ & & .000 & .000 & $\begin{array}{c}.002 \\
*\end{array}$ \\
\hline $\mathrm{F}$ & $\begin{array}{c}50.4 \\
4 * * *\end{array}$ & $\begin{array}{l}25.2 \\
1 * * *\end{array}$ & $\begin{array}{l}29.6 \\
0 * * *\end{array}$ & $\begin{array}{c}25.37 \\
* * *\end{array}$ & $\mathrm{~F}$ & $\begin{array}{l}24.5 \\
8^{* * * *}\end{array}$ & $\begin{array}{c}13.1 \\
7 * * *\end{array}$ & $\begin{array}{c}71.3 \\
2 * * *\end{array}$ & $\begin{array}{c}28.3 \\
3 * * *\end{array}$ & $\mathrm{~F}$ & $\begin{array}{c}141.01 \\
* * *\end{array}$ & $\begin{array}{c}70.61 \\
* * *\end{array}$ & $\begin{array}{c}70.66 \\
* * *\end{array}$ & $\begin{array}{c}72.8 \\
7 * * *\end{array}$ \\
\hline
\end{tabular}

\section{Discussion and Conclusions}

Previous studies have indicated that Taiwanese senior high school students spend less than one hour per week on reading for pleasure and instead focus mostly on academic-related activities (Chen \& Lu, 2009), though time spent on reading for pleasure does contribute to students' reading achievement as well as their general academic performance (Chen \& Fang, 2015; Chen \& Lu, 2009). Based on the Western literature related to the importance of content area literacy and disciplinary literacy, this study explored whether reading certain kinds of books 
could help students develop a corresponding literacy. In particular, we were interested in examining the potential utility of informational trade books.

To summarize, our study provided an understanding of the probable relationships between content-based pleasure reading and growth in achievement for not only the corresponding content area but also other content areas. We used the reading amounts recorded in a school-wide voluntary out-of-class reading program platform at a Taiwanese girls' high school as indicators for reading engagement with three broad content areas, literature, social studies, and science.

Our results indicated that, first, for students from both the Humanities \& Social Sciences classes and the Math \& Science classes reading for pleasure helped increase their academic achievement, but the former seemed to benefit a little more than the latter. Second, the results generally supported Moje and her colleagues' (2008) suggestion that pleasure reading in a specific genre or content area might lead to growth in achievement for that particular content area, with only one exception, which is that reading literature appeared to have no impact on achievement growth in Chinese for the Math \& Science majors-to-be. Third, the findings also suggested that in some cases, pleasure reading in other content areas helps growth in achievement for Chinese, social studies, and science, too.

Fourth, even though literature is the most popular genre among the three for both groups, reading social studies and science trade books appeared to have stronger linkages with academic achievement across content areas than did reading literature for both groups, but the patterns and degree of benefit seemed to depend somewhat on students' disposition the attitude toward heir future area of study. For example, reading social studies trade books appeared to enhance achievement growth across all three content areas for the Humanities \& Social Sciences majors-to-be and to benefit achievement in Chinese and social studies for Math \& Science majors-to-be In contrast, reading science trade books benefited social studies and science achievement for both groups. Reading literature, in contrast, benefited Chinese and science achievement for only the Humanities \& Social Sciences majors-to-be. It is significant to note that, as shown on the "Reading for Pleasure" platform, students' reading preferences in the content areas of social studies and science reflect an inclination toward informational books, or nonfiction, written by content experts with a contextualized literary style and rich disciplinary knowledge across a wide variety of topics. Overall, the findings of this study contribute to providing an initial linkage between content-based recreational reading and high school students' academic achievement in various subject areas, and to some degree this study has echoed the significance of disciplinary literacy.

Nevertheless, this study has at least two limitations. First, all of our subjects were from the same senior high school, and all were female with higher Social Economic Status. It might be interesting to probe whether the linkage between content-based recreational reading and growth in achievement holds for male students and students from lower SES families, or whether a stronger linkage would be found for other groups of students. Second, this study only had access to the number of books titles provided on the "Reading for Pleasure" platform, but other indicators might offer more accurate estimations for content-based books read for pleasure. Future studies are recommended to examine these issues. Furthermore, studies are also needed for more in-depth examinations to clarify possible connections between the content read and achievement in various subject areas.

Finally, extant studies have provided insight into and suggestions for how to promote adolescents' recreational book-reading practice (e.g., Merga, 2014; online first, 2016; Strommem \& Mates, 2004), and our study added a new dimension. We propose three key education implications that educators might consider: (a) a reading program that invites students to engage in self-sponsored content-based reading is a desirable approach for promoting disciplinary literacy and academic achievement; (b) the use of a variety of reading materials is recommended because students with different academic aptitudes and reading interests might benefit from different kinds of books; and (c) pleasure reading of quality books in social studies and science should be stressed because these books are quite helpful for high school students' academic learning. Considering the advice from teachers at the Zhong Shan Girls' High School into account, high schools can take the following actions: (a) create a school-wide reading program that includes a content-based reading list; (b) invite teachers from different disciplines to provide quality book titles related to their expertise; (c) provide a lot of information about each book as well as incentives for students to engage in self-sponsored reading; (d) avoid using these books as assignments; rather, honor students with reading ownership; (e) think about how to collect data in the long run to evaluate the impact and to adjust the program design and book titles; (f) in addition to print readings, offer multimodal resources for students to read for pleasure. 


\section{Acknowledgments}

We would like to thank the National Science Council of the Republic of China for financially supporting this research under Contract No. NSC 103-2420-H-007-003.

\section{References}

Anderson, R., Wilson, P., \& Fielding, L. (1988). Growth in reading and how children spend their time outside of school. Reading Research Quarterly, 23(3), 285-303. http://dx.doi.org/10.1598/RRQ.23.3.2

Chen, S. Y., \& Fang, S. P. (2015). Developing Chinese version of an author recognition test for college students in Taiwan. Journal of Research in Reading, 38(4), 344-360. http://dx.doi.org/10.1111/1467-9817.12018

Chen, S. Y., \& Fang, S. P. (2016). Print exposure of Taiwanese fifth graders-Measurement and prediction. Asia Pacific Educational Researcher, 25(1), 69-78. http://dx.doi.org/10.1007/s40299-015-0234-5

Chen, S. Y., \& Lu, L. (2009). After-school time use in Taiwan: Effects on educational achievement and well-being. Adolescence, 44(176), 891-910.

Daisey, P. (2010). Secondary preservice teachers remember their favorite reading experiences: Insights and implications for content area instruction. Journal of Adolescent \& Adult Literacy, 53(8), 678-687. http://dx.doi.org/10.1598/JAAL.53.8.6

Duhaylongsod, L., Snow, C. E., Selman, R. L., \& Donovan, M. S. (2015). Toward disciplinary literacy: Dilemmas and challenges in designing history curriculum to support middle school students. Harvard Educational Review, 85(4), 587-608. http://dx.doi.org/10.17763/0017-8055.85.4.587

Fang, Z. (2012). Approaches to developing content area literacies: A synthesis and a critique. Journal of Adolescent \& Adult Literacy, 56(2), 103-108. http://dx.doi.org/10.1002/JAAL.00110

Fang, Z. (2013). Disciplinary literacy in science: Developing science literacy through trade books. Journal of Adolescent \& Adult Literacy, 57(4), 274-278. http://dx.doi.org/10.1002/jaal.250

Fang, Z., \& Coatoam, S. (2013). Disciplinary literacy: What you want to know about it. Journal of Adolescent \& Adult Literacy, 56(8), 627-632. http://dx.doi.org/10.1002/JAAL.190

Fang, Z., \& Schleppegrell, M. J. (2010). Disciplinary literacies across content areas: Supporting secondary reading through functional language analysis. Journal of Adolescent \& Adult Literacy, 53(7), 587-597. http://dx.doi.org/10.1598/JAAL.53.7.6

Greaney, V. (1980). Factors related to amount and type of leisure reading. Reading Research Quarterly, 15(3), 337-357. http://dx.doi.org/10.2307/747419

Greaney, V., \& Hegarty, M. (1987). Correlates of leisure-time reading. Journal of Research in Reading, 10(1), 3-20. http://dx.doi.org/10.1111/j.1467-9817.1987.tb00278.x

International Reading Association. (2012). Adolescent Literacy: A Position Statement of the International Reading Association. Newark: DE: Author.

Lai, M. K., Wilson, A., McNaughtin, S., \& Hsiao, S. (2014). Improving achievement in sedondary schools: Impact of a literacy project on reading comprehension and secondary school qualifications. Reading Reearch Quarterly, 49(3), 305-334.

Marks, G., McMillan, J., \& Hilman, K. (2001). Tertiary Entrance Performance: The Role of Student Background and School Factors. Camberwell, Victoria: Australian Council for Educational Research.

Merga. M. K. (2014). What would make them read more? Insights from western Australian adolescents. Asia Pacific Journal of Education, 1-16.

Merga, M. K. (2016). "She knows what I like": Student-generated best-practice statements for encouraging recreational book reading in adolescents. Australian Journal of Education, 59(1), 35-50. http://dx.doi.org/10.1177/0004944114565115

Moje, E. B. (2008). Foregrounding the disciplines in secondary literacy teaching and learning: A call for change. Journal of Adolescent \& Adult Literacy, 52(2), 96-107. http://dx.doi.org/10.1598/JAAL.52.2.1

Moje, E. B., Overby, M., Tysvaer, N., \& Morris, K. (2008). The complex world of adolescent literacy: Myths, motivations, and mysteries. Harvard Education Review, 78(1), 107-154. http://dx.doi.org/10.17763/haer.78.1.54468j6204×24157 
Mol, S., \& Bus, A. (2011). To read or not to read: A meta-analysis of print exposure from infancy to early adulthoods. Psychological Bulletin, 137(2), 267-296. http://dx.doi.org/10.1037/a0021890

Reeves, A. R. (2004). Adolescents talk about reading: Exploring resistance to and engagement with text. Newark, DE: International Reading Association.

Saul, E. W., \& Dieckman, D. (2005). Choosing and using information trade books. Reading Research Quarterly, 40(4), 502-513. http://dx.doi.org/10.1598/RRQ.40.4.6

Snow, C. E. (2010). Academic language and the challenge of reading for learning about science. Science, 328(5977), 450-452. http://dx.doi.org/10.1126/science.1182597

Strommem, L. T., \& Mates, B. F. (2004). Learning to love reading: Interviews with older children and teens. Journal of Adolescent \& Adult Literacy, 48(3), 188-200. http://dx.doi.org/10.1598/JAAL.48.3.1

Taylor, B., Frye, P., \& Maruyama, G. (1990). Time spent reading and reading growth. American Educational Research Journal, 27(2), 442-451. http://dx.doi.org/10.3102/00028312027002351

Wilson, A. A. (2011). A social semiotics framework for conceptualizing content area literacies. Journal of Adolescent \& Adult Literacy, 54(6), 435-444. http://dx.doi.org/10.1598/JAAL.54.6.5

\section{Copyrights}

Copyright for this article is retained by the author(s), with first publication rights granted to the journal.

This is an open-access article distributed under the terms and conditions of the Creative Commons Attribution license (http://creativecommons.org/licenses/by/4.0/). 